\title{
ЛІТЕРАТУРОЗНАВСТВО
}

\section{ГОТИЧНІ ВІДЛУННЯ У МАЛІЙ ПРОЗІ МИХАЙЛА КОЦЮБИНСЬКОГО}

\author{
АННА ГОРНЯТКО-ШУМИЛОВИЧ \\ Університет імені Адама Міцкевича в Познані, Познань - Польща \\ GOTYCKIE REMINISCENCJE W MAŁEJ PROZIE \\ MYCHAJŁA KOCIUBYNSKIEGO \\ ANNA HORNIATKO-SZUMIŁOWICZ \\ Uniwersytet im. Adama Mickiewicza, Poznań — Polska
}

\begin{abstract}
STRESZCZENIE. Reminiscencje gotycyzmu literackiego, które ponownie dały znać o sobie w epoce neoromantyzmu stając się, obok wpływów neobarokowych, częścią składową ukraińskiego modernizmu, pojawiły się również w małej prozie Mychajła Kociubynskiego.

Ów znakomity pisarz sięga w swych utworach do konwencji powieści gotyckiej, buduje atmosferę grozy, stawia bohaterów w sytuacji granicznej, by wskazać na narastające problemy społeczne i jednocześnie pogłębić psychologizm utworów, w pełni zasługując na miano mistrza ukraińskiej prozy psychologicznej, twórcy na wskroś nowoczesnego, europejskiego.
\end{abstract}

\section{GOTHIC REMINISCENCE IN SMALL PROSE BY MYKHAILO KOTSIUBYNSKY}

\section{ANNA HORNIATKO-SZUMIŁOWICZ Adam Mickiewicz University, Poznan — Poland}

ABSTRACT. The reminiscence of literary Gothicism, that reappeared in the time of neoromanticism becoming, next to neo-Baroque influences, a component of the Ukrainian modernism, also appeared in the small prose by Mykhailo Kotsiubynsky.

This excellent writer applies Gothic novel convention in his works. He constructs the atmosphere of horror, puts his characters in a critical situation in order to indicate increasing social problems and to intensify the psychologism of his works. He deserves the title of the Ukrainian psychological prose master and a fully modern European author.

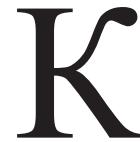

оли в 2000 році вийшла Антологія украӥнського жаху, що претендувала на роль „найстрашнішої книги в історії України” (Наталія Заболотна ${ }^{1}$ ), в яку ввійшли вибрані твори 3 фольклору, дещо 3 давньої літератури, а далі 32 автори, починаючи від зачинателя української художньої прози Григорія Квітки-Основ`яненка, а скінчивши на сучасному письменнику Андрію Дашкову, то посеред тієї плеяди творчих знаменитостей, з`явилось та-

${ }^{1}$ Н. Заболотна, Найстрашніша книга в історії Украӥни, [в:] Антологія українського жаху, упоряд., комент., післямова В. Пахарен ко, передм. Н. Забол отна, Київ 2000, с. 3. 
кож ім я класика Михайла Коцюбинського з його моторошним оповіданням Persona grata. Ця вражаюча розповідь про тупого злочинця-ката, душу якого поступово роз'їдає жах і мучать докори сумління, хоча не відповідає повністю моделі готичної прози в параметрах іiї найістотніших атрибутів: моторошності, таємничості, містичності, похмурості зображуваної атмосфери, нервової розладнаності, постійного передчуття близького лиха тощо, безперечно містить готичні відлуння.

Окрім названого вище оповідання, М. Коцюбинський написав щонайменше кілька творів, які об єднує „страшна” поетика, про що згадували видавці Антологіїукраїнського жаху. Це Сміх, Він іде, Невідомий, Подарунок на іменини. Перелік моторошних оповідань М. Коцюбинського можна поповнити за рахунок таких його творів, як Дебют, Що записано в книгу життя, Xо, Intermezzо чи Тіні забутих предків, у яких поза сумнівом наявні елементи літературного готицизму ${ }^{2}$.

${ }^{2}$ Українська готична проза, що, за влучним висловом Валерія Шевчука, цілком природна для українського письменства, оскільки „вона для нього відбиток національної ментальності”, добре вписується в європейський і світовий контексти. Наділена неповторним жанрово-тематичним й стильовим колоритом, зокрема, завдяки фольклорові, що неодмінно пов'язаний з українською літературою, вона залишалась у полі зору українських письменників від початків по сьогоднішній день. Окремі аспекти літературного готицизму розроблені в працях Валерія Шевчука, Юрія Винничука, Ігоря Качуровського, Василя Пахаренка, Івана Денисюка, Ігоря Лімборського, Христини Денисюк, Анни Горнятко-Шумилочич. (Див. напр.: В. Ше вч ук, 3 темних джерел жстття. Українська готична новела ХХ століття,, „Літературна Україна”, 1995, № 4, 5, 6; І. Л імборський, Західноєвропейський готичний роман і українська література, „Всесвіт”, 1998, nr 5-6, с. 157-162; В. Пах ар енко, Украӥнський фольклор, [в:] Антологія украӥнського жаху, упоряд. В. Пахарен ко, Київ, 2000, с. 5-6; В. Пах ар е н ко, Гериь зі страхом, [w:] Антологія українського жаху, упорядник В. Пахаренко, Київ 2000, с. 791-797; І. Качуровсь к и й, Готична література та їі жанри (Розділ із книги „Генерика і архітектоніка”), „Сучасність”, 2002, № 5, с. 59-67; I. О. Ден и сюк, Літературна тотика i Франкова проза, [в:] Літературознавчі та фольклористичні пращі: у 3 т., 4 книгах, Львів, 2005, т. 2: Франкознавчі дослідження, с. 196-197; Ю. Винничук, У зачарованім люстрі (Замість передмови), [в:] Потойбічне. Украйнська тотична проза XX cm., упоряд., вступне слово, бібліограф. відомості Ю. Винничука, Львів 2005, с. 3-8; Х. Денисюк, Готичний роман: специффіка жанру, [в:] Гуманітарна освіта в технічних вищих навчальних закладах: зб. наук. праць факультету Гуманітарного інституту Національно-авіаційного університету, Київ 2005, вип. 11, с. 286-293; В. Шевчук, У світі фантазій українського народу, [в:] Огняний змій. Украӥнська тотична проза XIX cm., уклав Ю. Винничук, Львів, 2006, с. 5-10; А. Горн я тко-Шуми лович, У дивосвіті новел Василя Габора (,Книга екзотичних снів та реальних подій”), [в:] „Слово і час”, 2006, № 11, c. 38-43; A. Horniatko-S zumiłowi c z, „Ognisty smok” Pantelejmona Kulisza, [w:] Jezyk. Człowiek. Dyskurs. Księga dedykowana prof. zw. dr hab. Michaiłowi Aleksiejence z okazji Jubileuszu 65-lecia urodzin, kol. red.: prof. dr hab. Florij Bacewicz i in., Szczecin 2007, s. 458-467; А. Гор н я тко-Щу м и о в и ч, Синтез барокового, готичного й романтичного начал y „Петріях $і$ Довбущуках” Івана Франка, [в:] Іван Франко: дух, наука, думка, воля. Матеріали Міжнародного наукового конгресу, присвяченого 160-річчю від дня народження Івана Франка, Львів 2008, т. 1, с. 241-253; А. Го рн я тко-Ш у м и л о в и ч, „Чайковський” Євгена Гребінки як химерний роман, [в:] „Наукові записки Тернопільського державного педагогічного університету імені В. Гнатюка”, серія „Літературознавство”: збірник. (Видається на пошану і з нагоди 60-річчя від дня народження докт. філол. наук, проф. Ткачука Миколи Платоновича), Тернопіль 2009, вип. 27, с. 54-58 та ін.).

Окремо тема традицій готицизму в українській літературі, а також питання дедалі більшого зацікавлення літературою жахів в українському суспільстві комплексно розроблена в статті нашого авторства: A. Horniatko-Szumiłowicz, $W$ kręgu opowieści niesamowitych, mrocznych tajemnic i fantastyki grozy (o tradycji gotycyzmu w literaturze ukraińskiej), [w:] Materiały XI Międzynarodowej Konferencji Naukowej „Słowo. Tekst. Czas” pt. Frazeologia słowiańska $w$ aspekcie onomazjologicznym, lingwokulturologicznym i frazeologicznym, pod red. W. Mokijenki, T. Szutkowskiego i Harrego Waltera, Szczecin- Greifswald 2012, s. 831-842. 
Михайло Коцюбинський - один із фундаторів українського модернізму, що, по суті, ввів в українську літературу імпресіонізм, справедливо вважається неперевершеним майстром психологічної малої прози кін. XIX - поч. XX ст. Головна риса його стилю - глибинний психологізм. I саме для творення гостропсихологічного оповідання письменник використовує готичну поетику.

У сучасному літературознавстві існує думка, що готичні відлуння стали, поруч з необароковими впливами, істотною складовою українського модернізму. У такому сенсі готичні прийоми сприяли руйнуванню класичного однолінійного сюжету та суттєвому поглибленню психологізму прози. Так, слушно писав у розвідці 3 темних джерел життя. Украӥнська готична новела ХХ століття (1995) Валерій Шевчук ${ }^{3}$ про однаковість художнього мислення деяких українських прозаїків XX ст., які, пишучи психологічний твір, використовували прийоми літературного готицизму. У їхньому числі Юрій Будяк з його „маленьким шедевром новели жаху" Петля, Павло Богацький, автор новели Камелії, Оля Галичанка (Олена Кисілевська) і ії твір 3 днів розпуки, новела Валерія Шевчука Хованець, врешті Олександр Жовна і його Вдовушка. До цього переліку можна зарахувати Історію Якимового будинку Володимира Винниченка, Страшну помилку Олексія Плюща, чи оповідання Михайла Могилянського, що дало назву вищеназваній розвідці Валерія Шевчука 3 темних джерел життя.

Дослідники звертають увагу на вплив М. Коцюбинського на прозаїків 2030 pp. XX ст., зокрема Григорія Косинку, Валеріана Підмогильного чи Юрія Яновського. Одним із перших, хто визнав вплив автора Тіней забутих предків на письменників свого покоління був Микола Зеров, який назвав прозаїка „піонером нової літературної школи"4. Поруч з імпресіоністськими стильовими тенденціями в прозі М. Коцюбинського, а то й суттєвого поглиблення іiі психологічного навантаження, предметом рефлексій письменника стають мотиви жаху й катастрофи, що набирають нової сили на поч. XX ст. Це безперечно пов'язано з подіями 1905-1907 pр., на які якраз випадає піднесення творчої активності письменника. Дослідники ${ }^{5}$ слушно зазначають, що апокаліптичним мотивам періоду 1906-1907 pp. у прозі М. Коцюбинського передують мотиви тривоги, страху, передчуття жаху, які стають початком цілого струменю в українській літературі (творчість Миколи Зерова, Свгена Плужника, Миколи Хвильового, Юрія Яновського). Таким чином, апокаліптичні візії, пов язані 3 революційними подіями 1905-1907 pp., є провідними для ряду оповідань М. Коцюбинського з готичною поетикою, насамперед Сміх, Він іде, Невідомий, Подарунок на іменини, Persona grata, Intermezzo.

У вказаних оповіданнях М. Коцюбинського наявні знакові атрибути літературного готицизму. Так, сюжети оповідань Він іде, Невідомий, Persona grata, Cмix розгортаються, подібно як в готичній прозі, в аурі таємничості й жаху, сповненій елементів несамовитості й містики. У всіх чотирьох творах автор підбирає для цього ситуацію критичну, кризову для героїв, що $є$ генератором емоційного напруження, душевних струсів, граничних реакцій. Провідними відчуттями є таємничість, страх, тривога й постійне очікування лиха. В нове-

${ }^{3}$ В. Ш е в чук, 3 темних джерел життя. Украйнська готична новела ХХ століття, [в:] „Літературна Україна” 1995, 26 січня.

${ }^{4}$ М. Зе р о в, Українське письменство, упоряд. М. Сули ма, післям. М. Москаленка, Київ 2002, c. 141.

${ }_{5}^{5}$ Див.: А. М. Менший, Михайло Коцюбинський і розвиток украӥнської літератури 20 30-x pp. XX cm., [в:] Електронний pecypc: http://archive.nbuv.gov.ua/portal/Soc_Gum/Nvmdu/ Fil/2011_4_7/15.htm (12.06.2013). 
лі Він іде - це страх єврейського населення малого містечка перед чорносотенним погромом (,, Тут притишеними, таємничими голосами, тривожно озираючись навкруги, переказували одні другим про якихсь непевних, чужих людей, що з'явились недавно в містечку, про чорносотенних панків, які були б раді погромові <..>"6), Невідомий - страх тюремника перед скорою стратою („Життя лишилось за сими мурами, а тут, серед сірих холодних стін, замкнулась 30 мною смерть. <.. > В кутку блимає лампка, а над нею нависла сіра і вогка, ворожа тиша"7), в Persona grata - жах, що поступово оволодіває катом після усвідомлення ним кількості заподіяного зла (,Часами на нього нападав страх. Усього боявся, все було вороже, все проти нього: закрадалось, чигало і не давало спокою"я). Також у новелі Сміх, що вважається першим творчим відгуком на події 1905-1907 pp., сугестивно передається жах адвоката Чубинського перед чороносотенним погромом: „Тепер, коли вони лишились самі, без людей, в цій темній хаті, оточеній чимсь грізним і невідомим, та намагались скрити в розмові один од одного свої думки і свій неспокій, тривога зростала, збиралась круг них немов гримлячий газ"'. I навіть у новелі Intermezzo, в якій готична аура не $є$ повсюдною, оскільки переплітається з ідилічним образом сільського літа, разом із настанням ночі, героя поглинає жах спогадів: „Десять чорних кімнат, налитих пітьмою по самі вінця. Вони облягають мою кімнату. Я зачиняю двері, наче боюся, що світло лампи витече все крізь шпари <..> А люди йдуть. За одним другий і третій і так без кінця. Вороги й друзі, близькі й сторонні і всі кричать у мої вуха криком свого життя або своєї смерті, і всі лишають на душі моїй сліди своїх підошов"

Дія вищеаналізованих творів М. Коцюбинського, як правило, розгортається в темних, понурих приміщеннях. У новелі Cміх „в хаті було темно і якось чудно"11. Ворожий настрій напруженого очікування лиха підсилює образ зачинених віконниць і тільки ,жовті зайчики світла тремтіли на стінах і на буфеті, вітер рвав віконниці і стукав ними"12. Інишим разом у новелі Він іде нагнітання тривоги здійснюється за допомогою картини опустошілого містечка: „на площі зробилось так пусто і тихо, наче весь вереск життя обернувсь раптом у сірий камінь" 13 . Для підсилення настрою жаху в новелі повторюються слова: жах („старезні мури тремтіли з жаху усіма зморшками стін”, „жах стулив всім уста”) і страшний (,,кожна хвилина, <..> наближала страшну невідомість”; „страшно чути спів”; „стає сумно і страшно, як в судний день”; „маки, такі страшні, червоні, .... як людська кров”; „хмара страшна і чорна” тощо) ${ }^{14}$.

Новела Невідомий побудована у формі потоку свідомості засудженого на страту. М. Коцюбинський вдається до прийому замкнення простору. Дія відбувається в маленькій тюремній камері, даючи автору поле для „мікроскопічного” дослідження душі героя. Нічна пора „серед сірих холодних стін”, у „холодному льоху" 15 підсилює відчуття неминучості страти. Атмосфера жаху поступово

${ }^{6}$ М. К Коцю би н с ь к и й , Він іде, [в:] його ж, Твори в 3 m., Київ 1979, т. 2: Оповідання (19011909), c. 185.

${ }^{7}$ М. Ко цюб и н с ь к и й , Невідомий, [в:] його ж, Твори в 3 m...., ор. cit. с. 194.

${ }^{8}$ М. Ко ц юб и н с ь к и й, Persona grata, [в:] його ж, Оповідання, Київ 1953, с. 221-222.

${ }^{9}$ М. К Коц юб и н с ь к и й, Смix, [в:] його ж, Оповідання..., ор. cit., с. 206.

${ }^{10}$ М. К Ко ц ю б и н с ь к и й, Intermezzo, [в:] його ж, Оповідання..., ор. cit., с. 246-248.

${ }^{11}$ М. Коц ю б и н с ь к и й, Смix, [в:] його ж, Оповідання..., ор. cit., с. 201.

${ }^{12}$ Там само.

${ }^{13}$ М. Ко ц юб и н с ь к и й, Він ide, [в:] його ж, Твори в 3 m...., op. cit., c. 186.

${ }^{14}$ Там само, с. $185,187,188,192,196$.

${ }^{15}$ М. Ко ц юб и н с ь к и й, Невідомий, [в:] його ж, Твори в 3 m...., op. cit., с. 194. 
нагнітається завдяки постійному повторюванні зворотів із концептами смерть і спорідненими з ним: „серед сірих холодних стін замкнулась зо мною смерть”; „як раптом линув потік житя у сю домовину...”; „дрібні істоти, що вмерли на небі, [пластівці снігу - A.Г.-Ш] спадали на землю, на вічний спочинок, у тихий цвинтар"; „ранок білий, імлистий, немов могильний саран” тощо ${ }^{16}$. Особливу роль відіграє нескінченна тиша: „сіра і вогка ворожа тиша”, „гробова тиша”17.

Дія вказаних творів М. Коцюбинського, як правило, відбувається вночі. Так, наприклад у новелі Він іде цілу ніч „в хаті старого шохата Абрума при світлі лойових свічок ішла нарада"18. В етюді Невідомий це остання ніч перед стратою. Тому й тюремнику здається, що смерть дивиться на його тінь ,з чорних кутків" "19. Коли це день - а скоріш всього світанок - землю пронизує крижаний холод, сірий туман, що підсилює настрій тривоги, приреченості, безнадії. „Був надзвичайно холодний ранок, коли я приїхав”20, — згадував Невідомий 3 однойменної новели. Прохолодне вологе вранішнє повітря тільки позірно віщує настання дня. В новелах М. Коцюбинського - це час страти, заповідь смерті, не життя. У цьому переконався кат Лазар з новели Persona grata („Потім звернули в поле. Стало ясніше і жита вже синіли, холодні та сіжі. < ..> Далеко на обрії чорнів лісок, а в долині під лісом слався туман, густий і білий, як вата. <..>> Лазар ще здалеку побачив стовп"21), але й десятилітній Доря 3 новели Подарунок на іменини. Хлопець, несвідомий, що їде ,дивитись, як будуть вішать" 22 , з радістю стежив за вранішнім краєвидом, що прокидається до життя: „Починало вже дніти. <..> Земля будилась”23. I тільки пізніше Доря побачив, що в „густих передранішніх тінях виразно біліють стовпи" 24 . Тут неодмінно хочеться згадати слова Івана Денисюка, який, досліджуючи елементи літературного готицизму у Франковій прозі, підкреслював, що в українській літературній готиці замість інтер ‘ ру понурих замків і підземель є здебільшого екстер’єр розкішна природа, „якась несамовито і фантастично гарна"25.

В арсеналі найбільш характерних реквізитів готичної поетики в малій прозі М. Коцюбинського велику роль відіграє окрема портретна деталь - очі та їх вираз. У новелі Він іде будуть це „сотки наляканих очей”26, загрожених чорносотенним погромом євреїв, і насамперед — „невидющі очі” старої Естерки, що втратила в погромі в Одесі двох синів. В етюді Невідомий смерть блимає на стратенця „кривавим оком”27. У новелі Сміх у битого чорносотенцями студента очі „такі великі, червоні, божевільні”28; страх перед реальним чорносотенним погромом мотивував те, що пан Чубинський дивився на наймичку Варвару „великими очима, наляканими, гострими і незвичайно видющими"29.

\footnotetext{
16 Там само, с. 194, 194-195, 197, 2003.

17 Там само, с. 194, 200.

${ }^{18}$ М. Ко ц Юб и н сь к и й, Він іде, [в:] його ж, Твори в трьох томах..., op. cit. с. 186.

${ }^{19}$ М. К Ко ц юб и н с ь к и й, Невідомий, [в:] його ж, Твори в трьох томах..., ор. cit., с. 194.

${ }^{20}$ Там само, с. 195.

${ }^{21}$ М. К Ко ц ю б и н с ь к и й, Persona grata, [в:] його ж, Оповідання..., op. cit. с. 217.

${ }_{22}^{2}$ М. Ко ц юб и н с ь к и й, Подарунок на іменини, [в:] його ж, Оповідання..., ор. cit., с. 275.

${ }^{23}$ Там само, с. 278-279.

${ }^{24}$ Там само, с. 280.

${ }^{25}$ I. Д е н и с ю к, Літературна готика і Франкова проза, [в:] того ж: Літературознавчі та фольклористичні праці в 3 m., 4 кн., Львів 2005, т. 2: Франкознавчі дослідження, с. 197.

${ }^{26}$ М. . Ко ц юб и н с ь к й , Він іде, [в:] його ж, Твори в 3 m...., op. cit., c. 190.

${ }^{27}$ М. . Ко ц юб и н с ь к и й, Невідомий, [в:] його ж, Твори в 3 m...., op. cit., с. 201

${ }^{28}$ М. К Коц юб и н с ь к и й, Сміх, [в:] його ж, Оповідання..., ор. cit., с. 205.

${ }^{29}$ Там само, с. 209.
} 
В оповіданні Persona grata людські очі відіграють особливу роль. У самого героя „в очах було щось скрите і щось запечатане” ${ }^{\text {. }}$. Згодом, коли став „казенною людиною” і призначений був для виконання смертної кари, „кожний 3 „клієнтів", стрічаючись з Лазарем в останню годину, лишав йому дещо на спомин: погляд, якийсь особливий і незвичайний" 31 . Поступово тупий кат починає бачити уві сні очі повішених ним стратенців. Їхні очі „верталися, лазили по обличчі, по шиї, грудях i, злегка лоскочучи, вертіли дірки углиб"з2. Тут очі стають збудником думки, імпульсом внутрішньої боротьби ката.

У вищеназваних творах можна помітити елементи т. зв. „ґотичної макабри”, моторошні сцени й епізоди. Так, напр., у новелі Persona grata наявні Лазареві спомини про знущання над котом (,обдертий, заморений кіт знов несподівано виплив, бився на мотузку, корчив хвіст, лапи і витріщав великі криваві очі”33), i, зокрема, жахливі подробиці страти приречених (,Часом вдавалось і робота виходила чисто. Іноді зашморг зсувався з шиї і крутив голову вбік. Тоді білий клунок скакав, корчився і довго не міг вмерти. Щоб покінчити муки, Лазар чіплявся за ноги, витягував тіло, аж щось хрустіло - i був кінець" "34). У новелі Intermezzo втомлений герой тікає з міста, щоб відпочити поміж пшеничних ланів, але й там знаходять його моторошні спогади про убієних: „От я їх вже бачу. Ба, ба! Як вас багато... Це ви, що з вас витекла кров в маленьку дірку від солдатської кульки, а це ви... сухі препарати: вас завивали у білі мішки, гойдали на мотузках в повітрі, а потому складали в погано прикриті ями, звідки вас вигрібали собаки..." $\left.{ }^{35}\right)$. Інколи це уявні жахливості, що є лихим передчуттям близької трагедії, як-от у новелі Він іде („Може, там бійка, може, там кров... Він нічого не знав, може, там ріжуть, грабують..." $\left.{ }^{36}\right)$.

Традиційний поділ на героїв позитивних і негативних, що набирає в класичному готичному романі форми поділу на переслідувачів та їхні жертви, тільки частково відображений у малій прозі М. Коцюбинського. По суті, лише кат Лазар $з$ новели Persona grata - постать однозначно негативна. Герой — це до певної міри приклад „готичного негідника” - людини жорстокої, злочинної, схильної до тиранії, ненависті, спроможної тортурувати, калічити, переслідувати, заподіювати смерть, що відображене як в його зовнішньому вигляді (,обличчя, скривлене гнівом, два вовчі ока, голі широкі груди, покриті волоссям, і кулаки" ${ }^{37}$ ), так і звірячій поведінці. Водночас під впливом романтичної антропології змінюється сам характер зла: із зовнішнього перетворюється на внутрішнє. Його джерелом стає людська природа, іiі двоїстість. Людина усвідомлює велич своєї злочинності й терпить муки сумління ${ }^{38}$. Так, Лазар, фізично й психічно надломлений, відчуваючи постійні докори совісті, морально прозріває: бо все ж він, за словами повішеної ним дівчини з русявим волоссям, „кращий за тих, що звеліли вбивати, бо не сокира рубає, а той, хто іiї держить..."39.

\footnotetext{
${ }^{30}$ М. К Ко ц ю б и н с ь к и й, Persona grata, [в:] його ж, Оповідання..., op. cit., с. 213.

31 Там само, с. 220.

32 Там само, с. 222.

33 Там само, с. 213.

34 Там само, с. 219-220.

${ }^{35}$ М. Ко ц юб и н с ь к и й, Intermezzo, [в:] його ж, Оповідання..., op. cit., с. 247.

${ }^{36}$ М. Коцюбинський, Він iде, [в:] його ж, Твори в 3 m...., op. cit., c. 191.

${ }^{37}$ М. К Ко ц юб и н с ь к и й, Persona grata, [в:] його ж, Оповідання..., op. cit., с. 226.

38 Див.: Powieść gotycka, [w:] Słownik literatury popularnej, pod red. T. Żabskiego, Wrocław
} 1997, s. 315.

${ }^{39}$ М. К Ко ц ю б и н с ь к и й, Persona grata, [в:] його ж, Оповiдання..., op, cit., с. 224. 
Прикметно, що М. Коцюбинський, по суті, у всіх названих творах обриває розповідь на півслові, підсилюючи настрій таємничості й всепоглинаючого страху. У новелах Сміх чи Він іде письменник - тонкий психолог, не дає безпосередньої картини погромів, але зосереджує увагу на емоційних переживаннях героїв. В обох випадках градація почуття жаху отримує свій апогей у заключних акордах тексту: - A-a-a... - котилось ближче щзось дике $i$ чулось в ньому i брязкіт скла, і окремі крики, повні розпуки та жаху, і тупіт ніг великої юрми. <..> Осінній вітер мчав жовті хмари й сам втікав з міста. - A-а-а...а-а-а... ${ }^{40}$ (Сміх); Прочесія все наближалась. Коли ж нарешті ї̈ обвіяв дух людської маси і обхопили страшні для неї голоси, сліпа Естерка стала, підняла руки, немов бажала спинити лаву, $і$ закричала <...>. I вона трясла кулаками і кричала словами, щзо лишались глибоко в грудях. Сльози, щзо спливали з невидющчх очей, заповняли старий чорний рот із двома пеньками жовтих зубів. А повз неї тупали тисячі ніг, дихали тисячі грудей, ревіли баси і танцьювали, як божевільні, дзвони. Великі, середні й маленькі... ${ }^{41}$ (Він іде). Надзвичайно вражаючі заключні фрази впритул підводять до граничної межі страху, геніально відображаючи настрій героїв, які чекають погрому, а то й неминучої смерті.

Симптоматичне й закінчення новели Persona grata: Tenep уже Лазар думав про нього. Хто він? Який? I де шукати? Йому уявлялось, щуо він такий, наче смотритель „морда” <...>. Лазар підходить близько до нього, до самої пики і каже: ти зло? <...> Потім він би його повісив. Не так, як других, ні, без запинала. <..> Він знає, як ие зробити: його навчили. I перший раз, після утоми $i$ знеохоти, після огиди до своєї роботи уперше почув він смак душегубства. Почув ненависть в серці і розкіш муки. Розповідь обривається раптово, залишаючи відчуття недомовленості. Замість подальшої розробки теми, письменник залишає читача зі свідомістю близької відплати Лазаря-ката кривднику, відповідальному за заподіяне зло, — йому і всім погиблим від катівської руки.

$$
* * *
$$

Свого часу Михайло Коцюбинський захоплювався готичною поетикою першоповісті його сучасника Івана Франка, пишучи, що в Петріях $i$ Довбущуках (1875) „Повно всякого страхіття, розбійників, заклятих скарбів, привидів, душегубства і оживаючих мерців"43. Особливості стилю Франкової повісті, про які натякнув автор Тіней забутих предків, позначились і на поетиці його прози, зокрема на низці новел та оповідань періоду 1906-1907 рр.. Однак, на відміну від Петріїв $i$ Довбущуків, влучно визначених І. Денисюком як ,роман готичний par exellence"44, в малій прозі М. Коцюбинського наявні лише елементи літературного готицизму, чи радше готичні відлуння як складова модерністських нововведень. Оскільки у I. Франка готичні атрибути спрацювали на розгортання сюжету роману „вольтерскотівського” типу, за учнівський характер якого, до речі, дорікали молодому I. Франку ${ }^{45}$, у М. Коцюбинського ж елементи готичної поетики вжиті з іншою метою. Утворюючи готичну напружену атмосфе-

\footnotetext{
${ }^{40}$ М. . Коц юб и н с ьк и й, Смiх, [в:] його ж, Оповідання..., оp. cit., с. 210.

${ }^{41}$ М. Ко ц юб и н сь к ий, Він іде, [в:] його ж, Твори в трьох томах..., op. cit., с. 192.

${ }^{42}$ М. К Ко ц ю б и н с ь к и й, Persona grata, [в:] його ж, Оповідання..., op. cit., с. 228.

${ }^{43}$ Цит. за: С . В . Щур а т, Рання творчість Івана Франка, Київ 1956, с. 172.

${ }^{44}$ I . Д е н и с ю к, Літературна тотика $і$ Франкова проза, ор. cit., с. 191.
}

45 Див., напр.: С. В. Щурат, Рання творчість Івана Франка, ор. cit., с. 145; С. В. Щурат, Повість Івана Франка „Петрії $і$ Довбушуки”, [в:] Іван Франко. Статті і матеріали, Збірник п`ятий, Львів 1956, с. 211; I. О. Дени сюк, Історична белетристика Івана Франка, [в:] Літературознавчі та фольклористичні праці у 3 m., 4 кн, Львів 2005, т. 2: Франкознавчі дослідження, с. 24 та ін. 
ру та поступово нагнітаючи іiі, автор ніби вказує на передчуття катастрофи, що наближається. Водночас, прискіпливо приглядаючись до поведінки героїв, поставлених у межові ситуації, їх плинної підсвідомості та свідомості, що стає реальністю за справою до краю загострених морально-етичних переживань, капітально поглиблює психологізм творів, заявляючи про себе як про письменника європейського масштабу, за словами згадуваного I. Франка, „наскрізь сучасного чоловіка" ${ }^{\prime 4}$.

${ }^{46}$ I. Денис юк, Розвиток української малої прози ХІХ - поч. ХХ ст., Львів 1999, с. 164. 